\title{
HIV-associated nephropathy: links, risks and management
}

This article was published in the following Dove Press journal: HIVIAIDS - Research and Palliative Care

\author{
Laura Palau',* \\ Steven Menez ${ }^{1, *}$ \\ Javier Rodriguez-Sanchez' \\ Tessa Novick' \\ Marco Delsante ${ }^{2}$ \\ Blaithin A McMahon' \\ Mohamed G Atta' \\ 'Department of Medicine, Johns \\ Hopkins School of Medicine, \\ Baltimore, MD, USA; ${ }^{2}$ Department of \\ Pathology, Johns Hopkins University, \\ Baltimore, MD, USA \\ *These authors contributed equally to \\ this work
}

\begin{abstract}
Despite the decreased incidence of human immunodeficiency virus (HIV)associated nephropathy due to the widespread use of combined active antiretroviral therapy, it remains one of the leading causes of end-stage renal disease (ESRD) in HIV-1 seropositive patients. Patients usually present with low CD4 count, high viral load and heavy proteinuria, with the pathologic findings of collapsing focal segmental glomerulosclerosis. Increased susceptibility exists in individuals with African descent, largely due to polymorphism in APOL1 gene. Other clinical risk factors include high viral load and low CD4 count. Advanced kidney disease and nephrotic range proteinuria have been associated with progression to ESRD. Improvement in kidney function has been observed after initiation of combined active antiretroviral therapy. Other treatment options, when clinically indicated, are inhibition of the renin-angiotensin system and corticosteroids. Further routine management approaches for patients with chronic kidney disease should be implemented. In patients with progression to ESRD, kidney transplant should be pursued, provided that viral load control is adequate. Screening for the presence of kidney disease upon detection of HIV-1 seropositivity in highrisk populations is recommended.
\end{abstract}

Keywords: HIVAN, HIV, APOL1 polymorphism, ESRD, kidney transplant

\section{Introduction}

Kidney disease is among the major causes of morbidity and mortality in human immunodeficiency virus (HIV)-1 positive individuals. ${ }^{1} \mathrm{HIV}$-associated nephropathy (HIVAN) is one of the most important causes of end-stage renal disease (ESRD) in this population. Factors such as African American ancestry, APOL1 polymorphisms, comorbidities, high viral load, low CD4 count, advanced kidney disease and nephrotic range proteinuria have been associated as risk factors for the development of HIVAN and its progression to ESRD. ${ }^{2}$ Concurrent with the widespread use of combined antiretroviral therapy (cART), prevalence of kidney disease in HIV-1 positive individuals has been increasing and is expected to rise further as a result of aging population and improved patients' survival. Existing management options for HIVAN range from cART, blockade of the renin-angiotensin system and steroids to renal replacement therapy with dialysis and, most recently, kidney transplant. In this review, we describe the trends in development of HIVAN and its currently accepted pathophysiology. An extensive PubMed review of the literature of HIV and associated kidney disease was performed. We will explore how the understanding of HIVAN has developed since its first description to the latest one.
Correspondence: Mohamed G Atta Department of Medicine, Johns Hopkins School of Medicine, 1830 E Monument Street, suite 416 , Baltimore, MD 2I287, USA

Email mattal@jhmi.edu 


\section{Pathophysiology}

HIVAN is pathologically characterized by a collapsing glomerulopathy with active tubulointerstitial inflammation. The collapse of glomerular basement membranes is usually observed, along with hypertrophy and hyperplasia of the overlying glomerular epithelial cells, as well as active tubulointerstitial disease manifested by microcytic tubular dilatation, interstitial inflammation and tubular injury (Figure 1). HIVAN presents clinically with a rapid rise in serum creatinine ( $\mathrm{sCr}$ ) and proteinuria. ${ }^{3,4}$ Other glomerular disorders can have a clinical presentation comparable to that of HIVAN and should be considered in this population (Table 1).

\section{Links and risks Host factors}

\section{African ancestry and genetic predisposition}

HIVAN predominantly affects HIV-1 positive individuals of African ancestry and its prevalence has been estimated to be as high as 3.5\% in clinical studies. ${ }^{5}$ According to a cohort from 1989 to 2011 of the United States Renal Data System, 89\% of patients with ESRD from HIVAN were African Americans. ${ }^{6}$ While the incidence of ESRD in HIV-positive individuals has decreased over time due to the widespread use of combined
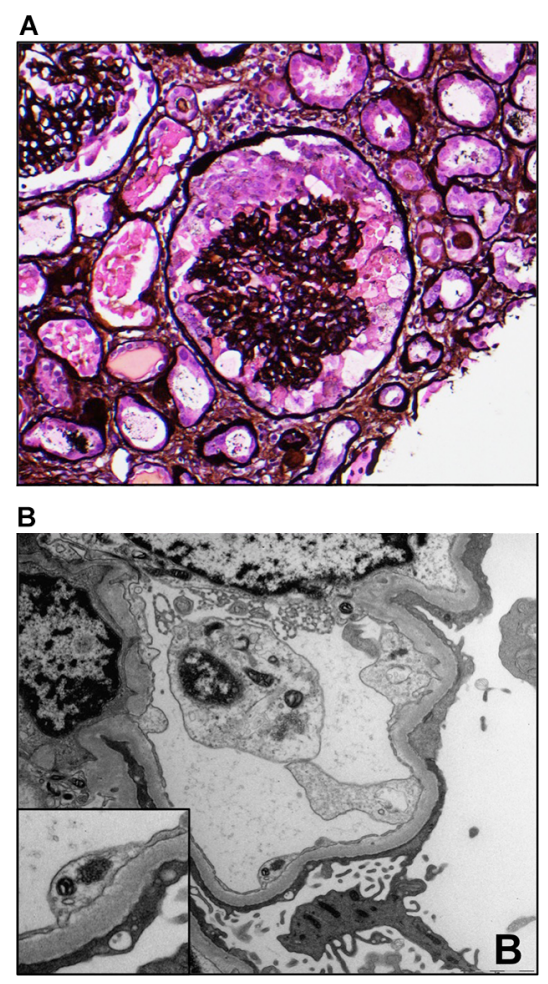

Figure I HIV-associated nephropathy.

Notes: (A) Collapsing glomerulopathy. The glomerular tuft is collapsed and marked podocyte hypertrophy is observed. Podocytes show marked protein overload. Light microscopy, silver-stained section, 200× magnification. (B) Diffuse podocyte injury with complete foot process effacement and focal microvillous transformation. A tubuloreticular inclusion is observed in an endothelial cell (box). Scanning electron microscopy, $6000 \times$ magnification. antiretroviral therapy (cART), HIV-positive individuals are still more likely than HIV-negative individuals to develop ESRD.

The increased risk in west African and African American populations has been demonstrated to be driven by polymorphisms in the APOL1 gene, as described by Genovese et al. ${ }^{7}$ Two APOL1 risk alleles, G1 (containing two missense mutations, rs73885319 and rs60910145) and G2 (a frameshift deletion rs71785313), at the serum resistance-associated interacting-domain-encoding region of $A P O L 1$ increase the susceptibility for the development of HIVAN. ${ }^{8}$ These two alleles appear to have arisen adaptively, possibly as a result of their protective effects against trypanosomal infections. Trypanosoma brucei rhodesiense, the cause of human African sleeping sickness, carries a serum resistance-associated protein that binds and inactivates the wild-type APOL1, preventing this from lysing the trypanosome. ${ }^{9}$ Individuals with two copies of the high-risk alleles have 29 times higher odds of developing HIVAN, as compared to those with zero risk alleles (odd ratio: $29,95 \%$ CI, $13-68) .{ }^{8}$ Until recently, the lack of animal models represented a major challenge to demonstrate the pathogenic effect of $A P O L 1$ risk alleles, since the $A P O L 1$ gene is only present in some primates and humans. The G1 allele was found in $52 \%$ of focal segmental glomerulosclerosis (FSGS) compared to $18 \%$ in geographically matched African American controls without kidney disease. The $\mathrm{G} 2$ allele, in contrast, was noted in $23 \%$ of FSGS cases compared to $15 \%$ in controls. ${ }^{7}$ APOL1 risk variants were associated with progression of kidney disease in a cohort of non-diabetic African Americans with hypertension-attributable kidney disease, regardless of blood pressure control target or antihypertensive agent. ${ }^{10}$

In vivo, mice with podocyte-specific expression of either APOL1 risk alleles develop albuminuria, foot-process effacement, glomerulosclerosis and gene expression changes reminiscent of human kidney disease. ${ }^{11}$ Although the mechanism by

Table I Differential diagnosis of HIV-associated nephropathy

- HIV-associated immune complex kidney disease

- Membranoproliferative glomerulonephritis (associated with concurrent hepatitis C infection)

- Classic FSGS

- Amyloidosis

- Minimal change disease

- Post-infectious glomerulonephritis

- Thrombotic microangiopathy

- Diabetic nephropathy

- Immunoglobulin A nephropathy

- Membranous glomerulopathy

Abbreviations: FSGS, focal segmental glomerulosclerosis; HIV, human immunodeficiency virus. 
which $A P O L 1$ variants cause kidney disease is not well defined, several studies have suggested several potential mechanisms.

In vitro studies by Granado et $\mathrm{al}^{12}$ showed that APOL1 proteins localize intracellularly, predominantly in the endoplasmic reticulum and to a lesser extent in the mitochondria in podocyte cells. In comparison to the G0 wild-type variant, in vitro overexpression of G1 and G2 led to an increase in phosphorylation of stress-triggered kinases such as the p38 MAPK and AMP-activated protein kinase. This ultimately led to adenosine triphosphate depletion and increased cytotoxicity, indicating $A P O L 1$-associated cellular injury is induced by decreased functioning at these particular sites. In another study using T-Rex-293 cells lines, overexpression of G1 or G2 APOL1 risk variants led to an apparent cell swelling, potassium depletion and activation of stress-activated protein kinases, resulting in a dose-dependent cell injury. ${ }^{13}$ Most recently, Ma et al demonstrated in vitro that overexpression of G1 and G2 alleles led to impaired mitochondrial function, resulting in cell injury and death characterized by intracellular potassium depletion. ${ }^{14}$ The authors postulated that this could be due to disruption of the sodium-potassium ATPase activity and with changes in membrane potential, a cascade of events can ensue leading ultimately to cell injury and death.
Another novel mechanism for $A P O L 1$-induced kidney injury in vivo used a transgenic Drosophila fly line expressing G0 vs G1 variants, which resulted in nephrocyte hypertrophy and accelerated cell death. ${ }^{15}$ The authors note that the Drosophila nephrocyte has a very similar structural and functional homology to mammalian podocytes, which has been the target of previous in vitro research. Finally, a group led by Kruzel-Davila showed another potential pathway to cell injury via impaired vacuole acidification and impaired endosomal trafficking using Drosophila melanogaster and the yeast Saccharomyces cerevisiae. ${ }^{16}$

The strong associations of the APOL1 risk alleles have been described in multiple case-control and population studies of kidney disease in patients with ESRD, FSGS, HIVAN and hypertension-attributed nephropathy. This association has more recently been extended to certain glomerulopathies such as systemic lupus erythematosus, membranous nephropathy and diabetic kidney disease (Figure 2).${ }^{17}$ However, currently, the possible association of $A P O L 1$ risk alleles with these glomerulopathies may not represent development of the specific glomerulopathy per se, but rather $A P O L 1$-associated glomerulopathies (e.g., FSGS in a patient with systemic lupus erythematosus) and requires further investigation.

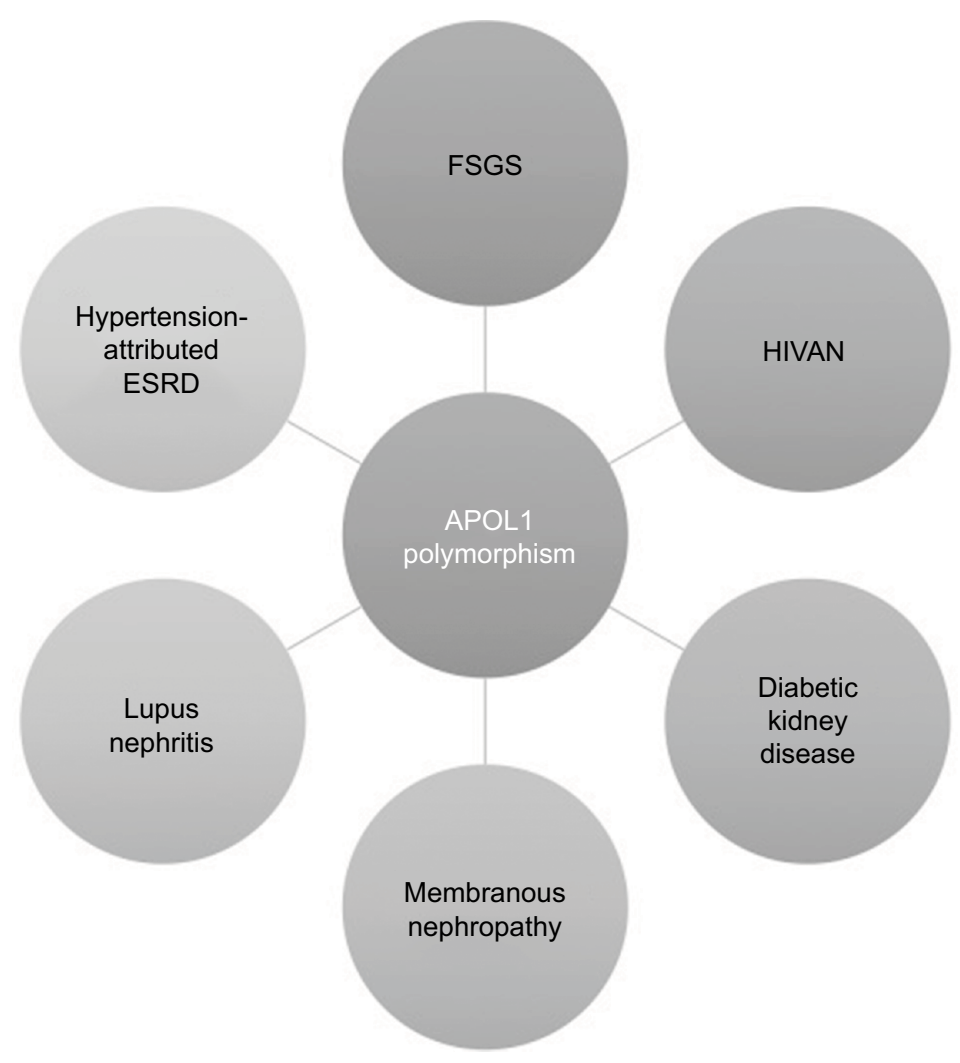

Figure 2 Spectrum of APOLI-associated kidney diseases.

Abbreviations: ESRD, end-stage renal disease; FSGS, focal segmental glomerulosclerosis; HIVAN, human immunodeficiency virus-associated nephropathy. 


\section{Male sex and age}

Previous studies have shown that individuals with HIVAN are predominantly male. Based on the data from United States Renal Data System, 70\% of ESRD patients with HIVAN were male. While older age has been reportedly associated with HIVAN, ${ }^{18,19}$ median age among several other studies appears to be from 35 to 48 years. ${ }^{6,20,21}$ However, studies have failed to show a direct correlation between gender or age and HIVAN.

\section{Heavy proteinuria}

Classically, HIVAN presents with rapidly declining glomerular filtration rate (GFR) and nephrotic range proteinuria. In one study characterizing 57 patients with HIVAN on kidney biopsy, mean proteinuria was $4.1 \mathrm{~g} /$ day and only $14 \%$ of the patients had proteinuria $<1.5 \mathrm{~g} /$ day. ${ }^{22}$ Atta et al established that the sensitivity and specificity of nephrotic range proteinuria for identifying HIVAN in HIV-positive individuals were 73\% and $61 \%$, respectively. ${ }^{23} \mathrm{~A}$ summary of the risk factors and predictors of HIVAN and its progression is listed in Table 2.

\section{Comorbidities - diabetes mellitus and hypertension}

Diabetes mellitus and hypertension have been reported as the most frequent causes of chronic kidney disease (CKD) in the US general population, increasing the CKD risk almost 10 -fold and accounting for $71 \%$ of all cases of ESRD..$^{24,25}$ Diabetes and hypertension are increasingly frequent, and are potential drivers for CKD progression in individuals with coexisting HIVAN. Several studies have shown increased odds of diabetes and hypertension in HIV-positive individuals compared to seronegative controls. ${ }^{26-30}$ Furthermore, in cross-sectional and cohort studies, the prevalence of hypertension and diabetes approaches $55 \%$ and $20 \%$, respectively. A possible explanation of this is that the use of ART can lead to altered lipid metabolism, dysregulation of glucose control and lipodystrophy, which are traditional risk factors that contribute to the development of CKD. ${ }^{31}$

\section{Reduced kidney function or estimated GFR (eGFR) $<90 \mathrm{~mL} / \mathrm{min} / 1.73 \mathrm{~m}^{2}$}

Due to the rapid progressive course of HIVAN, kidney function may be severely reduced at the time of diagnosis. Bige

Table 2 Risk factors and predictors of HIV-associated nephropathy

- Black race ${ }^{5,6}$

- GI/G2 high-risk alleles for APOLI ${ }^{7-9}$

- CD4 count $<200 / \mathrm{mL}$, high viral load $>400$ copies $/ \mathrm{mL}^{29,32-34}$

- Proteinuria $>3 \mathrm{~g} /$ day $^{20,21}$

- eGFR $<90 \mathrm{~mL} / \mathrm{min}$, serum creatinine elevated from baseline $\mathrm{e}^{20,30,31}$

Abbreviations: eGFR, estimated glomerular filtration rate; HIV, human immunodeficiency virus. et al reported severely impaired kidney function in their cART-treated patient population, with a median eGFR of 20 $\mathrm{mL} / \mathrm{min} / 1.73 \mathrm{~m}^{2}{ }^{22}$ Higher $\mathrm{sCr}$ at the time of presentation in HIV-positive patients is also associated with the diagnosis of HIVAN. In a study that included 87 patients, mean baseline $\mathrm{sCr}$ in patients with HIVAN was $7.6 \mathrm{mg} / \mathrm{dL}$ compared with $2.5 \mathrm{mg} / \mathrm{dL}$ in patients without HIVAN, ${ }^{32}$ and can be a strong negative predictor for HIVAN diagnosis. ${ }^{33}$

\section{Viral factors}

\section{Advanced HIV disease (low CD4, high viral load)}

Advanced HIV-1 infection is often found in patients with HIVAN. Based on the results of two studies, $\sim 80 \%-90 \%$ of the patients who present with HIVAN have a CD4-positive T-cell count $<200$ cells $/ \mathrm{mm}^{3}{ }^{3}{ }^{31,34}$ In a 57 -patient study with biopsy-proven HIVAN, the mean HIV viral load was $>30,000$ copies $/ \mathrm{mL}$ and the mean CD4 count was 127 cells $/ \mathrm{mm}^{3}{ }^{32}$ HIV-1 RNA levels can help in suggesting the emergence of HIVAN in a patient with typical clinical presentation or otherwise its absence if HIV-1 RNA level is $<400$ copies/ $\mathrm{mL} .{ }^{35} \mathrm{HIV}-1$ RNA level of $\geq 400$ copies $/ \mathrm{mL}$ resulted in a high sensitivity of $95.8 \%$, but with a low specificity of $35.5 \%$ for the diagnosis of HIVAN. Moreover, intracellular HIV-1 proviral DNA level in peripheral blood mononuclear cells may also predict the likeliness of developing HIVAN. An intracellular HIV-1 proviral DNA level $<10$ copies $/ \mathrm{ml} \mathrm{had}$ a negative predictive value and sensitivity of $100 \%$ for the diagnosis of HIVAN. ${ }^{36}$

\section{HIV infection of renal cells}

The pathogenesis of HIV-associated kidney disease is poorly understood. The proposed mechanisms include direct infection of renal parenchymal cells and indirect injury to the kidney by renal cellular uptake of circulating virally encoded molecules or indirect injury through the release of cytokines. Also, multiple mechanisms might be involved when different HIV variants are present. ${ }^{37}$ However, the mechanism by which HIV-1 enters these cells has not been identified. Renal tubular cells do not express any of the known HIV-1 receptors (CD4, CCR5, CXCR4, DC-sign or mannose receptors). ${ }^{37,38}$ A previous study assessing the role of DEC-205 as an HIV-1 receptor in mediating internalization of the virus into renal tubular cells has been proposed. ${ }^{39}$

\section{Management}

Currently, there are no randomized controlled trials that address the management of HIVAN. Most of the treatment options including cART, inhibition of renin-aldosterone 
system and corticosteroids are based on retrospective studies and small non-randomized trials (Table 3).

\section{Combined active ART}

Clinical practice guidelines recommend ART initiation in all HIV-positive individuals, regardless of their CD4 count.
HIVAN generally affects patients with advanced HIV-1 infection who would require treatment regardless of renal involvement, making it difficult to perform randomized clinical trials to evaluate the efficiency of cART in this population. Thus, evidence-based recommendations for cART in patients with HIVAN come mainly from observational or retrospective

Table 3 Summary of previous studies regarding management

\begin{tabular}{|c|c|c|c|c|c|}
\hline Management & $\begin{array}{l}\text { Author, journal, } \\
\text { year of study }\end{array}$ & $\begin{array}{l}\text { Patient } \\
\text { population }\end{array}$ & $\begin{array}{l}\text { Type of } \\
\text { study }\end{array}$ & Outcome & Reference \\
\hline \multirow[t]{2}{*}{ cART } & $\begin{array}{l}\text { Atta MG, Gallant } \\
\text { JE, Rahman MH, } \\
\text { et al. Nephrol Dial } \\
\text { Transplantat. } 2006\end{array}$ & $\begin{array}{l}263 \text { consecutive } \\
\text { HIV-infected } \\
\text { patients }\end{array}$ & Retrospective & $\begin{array}{l}\text { Renal survival was significantly better in the group } \\
\text { receiving ART by both univariate }(p=0.025) \text { and } \\
\text { multivariate analyses }(p<0.05) \text {, compared with no } \\
\text { treatment }\end{array}$ & 40 \\
\hline & $\begin{array}{l}\text { Lucas GM, Eustace JA, } \\
\text { Sozio S, Mentari EK, } \\
\text { Appiah KA, Moore } \\
\text { RD. AIDS. } 2004\end{array}$ & $\begin{array}{l}4000 \text { HIV-positive } \\
\text { patients, clinical } \\
\text { diagnosis of HIVAN }\end{array}$ & $\begin{array}{l}\text { I2-year cohort } \\
\text { study }\end{array}$ & $\begin{array}{l}\text { The HIVAN risk was reduced to } 60 \%(95 \% \mathrm{Cl} \text {, } \\
-30 \% \text { to }-80 \%) \text { by use of HAART }\end{array}$ & 39 \\
\hline \multirow[t]{2}{*}{$\begin{array}{l}\text { ACE inhibitors/ } \\
\text { ARB }\end{array}$} & $\begin{array}{l}\text { Kimmel PL, Mishkin } \\
\text { GJ, Umana WO. Am J } \\
\text { Kidney Dis } 1996\end{array}$ & $\begin{array}{l}\text { I } 8 \text { patients with } \\
\text { biopsy-proved } \\
\text { HIVAN }\end{array}$ & $\begin{array}{l}\text { Case-control } \\
\text { study }\end{array}$ & $\begin{array}{l}\text { Renal survival was significantly enhanced in } \\
\text { patients treated with captopril vs controls (mean } \\
\text { renal survival } 156 \pm 7 \text { I vs } 37 \pm 5 \text { days, respectively; } \\
p<0.002 \text { ) }\end{array}$ & 42 \\
\hline & $\begin{array}{l}\text { Wei A, Burns GC, } \\
\text { Williams BA, et al. } \\
\text { Kidney Int } 2003\end{array}$ & $\begin{array}{l}44 \text { patients with } \\
\text { biopsy-proven HIV }\end{array}$ & $\begin{array}{l}\text { Prospective } \\
\text { study }\end{array}$ & $\begin{array}{l}\text { Longer renal survival for HIV-positive patients } \\
\text { treated with fosinopril as compared to untreated } \\
\text { patients (relative risk: } 0.003 ; p<0.000 \text { I) }\end{array}$ & 43 \\
\hline \multirow[t]{2}{*}{ Corticosteroids } & $\begin{array}{l}\text { Eustace JA, } \\
\text { Nuermberger E, } \\
\text { Choi M, Scheel PJ, Jr, } \\
\text { Moore R, Briggs WA. } \\
\text { Kidney Int. } 2000\end{array}$ & $\begin{array}{l}\text { 2I patients with } \\
\text { biopsy-proved } \\
\text { HIVAN }\end{array}$ & $\begin{array}{l}\text { Retrospective } \\
\text { cohort }\end{array}$ & $\begin{array}{l}\text { The relative risk }(95 \% \mathrm{Cl}) \text { for progressive } \\
\text { azotemia with corticosteroid treatment at } 3 \\
\text { months was } 0.20(0.05,0.76, p<0.05) \text {. A limited } \\
\text { course of corticosteroid therapy in selected } \\
\text { patients was beneficial and safe }\end{array}$ & 45 \\
\hline & $\begin{array}{l}\text { Laradi A, Mallet A, } \\
\text { Beaufils H, et al. J Am } \\
\text { Soc Nephrol. } 1998\end{array}$ & $\begin{array}{l}\text { I02 patients with } \\
\text { biopsy-proven } \\
\text { HIVAN }\end{array}$ & $\begin{array}{l}\text { Retrospective } \\
\text { study }\end{array}$ & $\begin{array}{l}\text { Delay in the initiation of hemodialysis was } \\
\text { observed. The proportion of patients free of } \\
\text { dialysis at } 0.5, \text { I and } 3 \text { years was } 73 \% \pm 5 \%, 60 \% \pm 7 \% \\
\text { and } 18 \% \pm 10 \% \text {, respectively }\end{array}$ & 46 \\
\hline \multirow[t]{4}{*}{$\begin{array}{l}\text { Kidney } \\
\text { transplantation }\end{array}$} & $\begin{array}{l}\text { Stock PG, Barin B, } \\
\text { Murphy B, et al. N } \\
\text { Engl J Med } 2010\end{array}$ & $\begin{array}{l}\text { I50 HIV-positive } \\
\text { patients }\end{array}$ & $\begin{array}{l}\text { Multicenter, } \\
\text { prospective } \\
\text { non- } \\
\text { randomized, } \\
\text { 3-year trial }\end{array}$ & $\begin{array}{l}\text { A higher-than-expected rejection rate was } \\
\text { observed, with I- and } 3 \text { year estimates of } 31 \% \\
(95 \% \mathrm{Cl}, 24-40) \text { and } 41 \%(95 \% \mathrm{Cl}, 32-52) \text {, } \\
\text { respectively }\end{array}$ & 53 \\
\hline & $\begin{array}{l}\text { Waheed S, Sakr A, } \\
\text { Chheda ND, et al. } \\
\text { PLoS ONE. } 2015\end{array}$ & $\begin{array}{l}\text { I I patients with } \\
\text { biopsy-proven } \\
\text { HIVAN }\end{array}$ & $\begin{array}{l}\text { Retrospective } \\
\text { analysis }\end{array}$ & $\begin{array}{l}\text { Delayed graft function: } 64 \% \text {; required } \\
\text { postoperative dialysis within I week of transplant: } \\
54 \% \text {. Graft survival rates at I and } 3 \text { years were } \\
100 \% \text { and } 81 \% \text {, respectively, and acute rejection } \\
\text { rates at I and } 3 \text { years were I } 8 \% \text { and } 27 \% \text {, } \\
\text { respectively }\end{array}$ & 54 \\
\hline & $\begin{array}{l}\text { Muller E, Barday Z, } \\
\text { Mendelson M, et al. } \\
\text { N Engl J Med. } 2015\end{array}$ & $\begin{array}{l}27 \text { HIV-positive } \\
\text { patients }\end{array}$ & $\begin{array}{l}\text { Prospective } \\
\text { non- } \\
\text { randomized } \\
\text { study }\end{array}$ & $\begin{array}{l}\text { Rejection rates were } 8 \% \text { at I year and } 22 \% \text { at } \\
3 \text { years }\end{array}$ & 55 \\
\hline & $\begin{array}{l}\text { Muller E, Barday Z. } \\
\text { J Am Soc Nephrol. } 2018\end{array}$ & $\begin{array}{l}43 \text { kidneys from } \\
25 \text { HIV-positive } \\
\text { deceased donors } \\
\text { transplanted into } \\
\text { HIV-positive } \\
\text { patients }\end{array}$ & $\begin{array}{l}\text { Prospective, } \\
\text { non- } \\
\text { randomized } \\
\text { study }\end{array}$ & $\begin{array}{l}\text { Since } 2008,43 \text { kidneys from } 25 \text { HIV-positive } \\
\text { deceased donors have been transplanted into } \\
\text { patients who are HIV positive in Cape Town, } \\
\text { South Africa } \\
\text { Only one recipient experienced an increased viral } \\
\text { load after the transplant, which was related to a } \\
\text { period of noncompliance on her medication }\end{array}$ & 57 \\
\hline
\end{tabular}

Abbreviations: ACE, angiotensin-converting enzyme; ARB, angiotensin receptor blocker; ART, active antiretroviral therapy; cART, combined active antiretroviral therapy; HAART, highly active antiretroviral therapy; HIV, human immunodeficiency virus; HIVAN, HIV-associated nephropathy. 
studies. In a retrospective cohort study that included patients with HIVAN not on dialysis, renal survival was significantly better in the patients treated with cART compared to patients with no treatment. ${ }^{40}$ In a cohort of 4000 patients with HIV, the difference in incidence rate of HIVAN in those receiving and not receiving cART was 19.6 per 1000 patients per year (26.4 vs 6.8 per 1000 patients per year). The HIVAN risk was reduced by $60 \%(95 \% \mathrm{CI},-30 \%$ to $-80 \%)$ with cART. ${ }^{41}$ Notably, Post et al followed a large cohort of HIV-positive patients from 1998 to 2004, of whom 61 were diagnosed with HIVAN (45 biopsy proven). ${ }^{42}$ These authors showed that despite improvement in overall survival with the use of cART, renal survival remained poor, with 34 patients reaching ESRD, including even those who had achieved complete viral suppression. However, as pointed out by the authors, most of these patients already had advanced renal failure at the time of HIVAN diagnosis; also, there was no control untreated group in this study.

\section{Renin-angiotensin-aldosterone system blockade}

No randomized trials of renin-angiotensin-aldosterone system blockade in patients with HIV-related CKD have been conducted. Most studies concerning the use of angiotensinconverting enzyme (ACE) inhibitors/angiotensin receptor blockers (ARBs) have been extrapolated from studies in other glomerular diseases or from the pre-cART era. ACE inhibitors/ARBs have been shown to be effective in CKD. ${ }^{43}$ Such protective effects are mainly due to decreased intraglomerular pressure, decrease in inflammatory mediators and reduction in proteinuria independent of blood pressure control. ${ }^{44}$ From the few studies addressing ACE inhibitors/ARBs, Kimmel et al studied 18 patients with biopsy-proven HIVAN, of whom nine patients were treated. They showed that renal survival was significantly enhanced in patients treated with captopril vs controls (mean renal survival $156 \pm 71$ vs $37 \pm 5$ days, respectively; $p<0.002) .{ }^{45}$ A subsequent study demonstrated significantly longer renal survival for HIV-positive patients treated with fosinopril as compared to untreated patients (relative risk: $0.003 ; p<0.0001){ }^{46}$

Treatment with ACE inhibitor/ARB is recommended, when clinically feasible, in HIV-positive individuals with confirmed or suspected HIVAN or clinically significant albuminuria (>30 mg/day in diabetic patients and $>300 \mathrm{mg}$ / day in non-diabetic patients). ${ }^{47}$

\section{Corticosteroids}

Despite the lack of large randomized controlled trials to support steroid use in this population, the rationale behind steroid use in patients with HIVAN comes from the significant tubulointerstitial inflammation shown on renal biopsy in these individuals. After steroid treatment, the inflammation was found to improve. In a small retrospective study including $21 \mathrm{HIV}$-positive individuals of whom 13 received prednisone $60 \mathrm{mg}$ /day for $1 \mathrm{month}, 7$ remained dialysis free at 6 months compared to only 1 of the 8 non steroid treated individuals. ${ }^{48}$ In another retrospective cohort of 102 biopsyproven HIVAN cases, delay in the initiation of hemodialysis was seen in individuals who received prednisone at $1 \mathrm{mg} / \mathrm{kg}$ for 2-6 weeks. The proportion of patients free of dialysis at $0.5,1$ and 3 years was $73 \% \pm 5 \%, 60 \% \pm 7 \%$ and $18 \% \pm 10 \%$, respectively. ${ }^{49} \mathrm{HIV}$ Medicine Association of the Infectious Diseases Society of America clinical practice guidelines suggest that clinicians can consider corticosteroids as an adjunct to ART and ACE inhibitors or ARBs in biopsyconfirmed HIVAN. ${ }^{47}$

\section{Renal replacement therapy in HIVAN}

Due to the rapid disease progression, HIVAN often advances to ESRD requiring renal replacement therapy, despite HIV treatment. Risk factors for the development of ESRD in HIVpositive individuals include traditional risk factors such as hypertension, diabetes mellitus, cardiovascular disease and HIV-associated factors such as low CD4 counts and high HIV RNA levels. ${ }^{50}$ In a cohort study performed in Denmark, individuals with HIVAN showed a 4-fold increased requirement for any requirement for renal replacement therapy and a 3-fold increased requirement for chronic renal replacement therapy compared to the seronegative population, with no association to cART. ${ }^{51}$ Although some studies have suggested that overall long-term survival is possible in patients with HIVAN on dialysis, older age, presence of lower serum albumin level, low CD4 count and the lack of cART are independent predictors of poor survival. ${ }^{52,53}$ Regarding the incidence of dialysis access infection, rates for prosthetic arteriovenous graft infection in HIV-positive patients and HIV-negative patients were $30 \%$ and $7 \%$, respectively $(p=0.04)$. Infection rates in autologous arteriovenous fistulas did not differ between the groups. ${ }^{54}$ Patient to patient transmission of HIV has not been documented in the USA, and thus, the Center for Disease Control does not recommend routine isolation or dedicated machines for HIV-infected patients, unless there is a coinfection with hepatitis B. ${ }^{55}$

\section{Kidney transplantation}

An increasing number of HIV-positive individuals with ESRD are seeking kidney transplantation. A multicenter, 
prospective, 3-year trial examined outcomes of kidney transplantation in $150 \mathrm{HIV}$-positive individuals who had CD4 counts of at least 200 cells $/ \mathrm{mL}$ and undetectable HIV-1 RNA levels ( $<50$ copies $/ \mathrm{mL}$ ) or $<75$ copies $/ \mathrm{mL}$ on viral load while receiving cART in the 16 weeks prior to transplantation. Median follow-up was 1.7 years. Unexpectedly, the study reported a higher rejection rate by $2-3$-fold increase in HIV-positive individuals compared with HIV-negative individuals. However, the 1- and 3-year allograft survival was reasonable at $90 \%$ and $74 \%$, respectively. ${ }^{56}$ Waheed et al examined transplant recipients with HIVAN and its impact on graft and patient survival in HIV-1 positive individuals who underwent kidney transplantation at a large tertiary care center from 2006 to 2014 . They included 16 individuals with HIV-1 seropositivity who underwent kidney transplantation. Of these, 11 patients were identified to have biopsy-proven HIVAN as the primary cause of their ESRD. Seven (64\%) individuals developed delayed graft function, of whom six (54\%) required postoperative dialysis within 1 week of transplant. Graft survival rates at 1 and 3 years were 100\% and $81 \%$, respectively, and acute rejection rates at 1 and 3 years were $18 \%$ and $27 \%$, respectively. ${ }^{57}$

In recent years, kidney transplantation has been successfully implemented from HIV-positive donors to HIV-positive recipients, both in South Africa and in the USA. ${ }^{58,59}$ While HIV-negative donor to HIV-positive recipient kidney transplantation has been carried out since 2001, the concerns regarding HIV-positive to $\mathrm{HIV}$-positive transplantation include HIV superinfection, resistance to cART and potential recurrence of HIVAN, in addition to inferior outcomes in general. ${ }^{60}$ While short-term end points have shown promise, long-term outcome data have been somewhat lacking. A more recent study detailed the outcomes of kidney transplantation from a HIV-positive donor to a HIV-positive recipient from 2008 to $2017,{ }^{60}$ totaling 43 kidneys transplanted from 25 HIV-positive deceased donors to HIV-positive recipients. Notably, 23 of the 25 deceased donors had not received any type of cART. Among the 43 recipients, 6 had protocol biopsies that were concerning for recurrent HIVAN. However, the authors argue that in certain areas of the world, including South Africa, the risk of shortened transplant kidney survival using HIV-positive donor kidneys far outweighs the risk of advanced CKD, given the lack of access to dialysis.

\section{Routine CKD care - blood pressure control, vaccinations}

Screening and early diagnosis of CKD will improve outcomes in patients who are HIV positive. From the renal standpoint, strategies for care in HIV-positive individuals should include measurement of blood pressure, kidney function ( $\mathrm{sCr}$, eGFR), urine examination of proteinuria, administration and monitoring of cART and/or ACE inhibitors/ARBs. Patient should be referred to a nephrology service for early CKD management, predominantly to distinguish cART nephrotoxicity from other non-HIVAN-related kidney disorders, monitoring disease progression and complications and ultimately for timely preparation for dialysis and/or kidney transplantation. Establishing the level of kidney function is important in minimizing nephrotoxicity of cART, considering that the majority of patients worldwide receive tenofovir-based regimens as first-line therapy. Moreover, given the broad differential diagnosis in HIV-1-positive individuals, a kidney biopsy may be an essential tool for evaluation. ${ }^{61}$ The high incidence of hypertension and diabetes mellitus in HIVAN underscores the importance of optimizing blood pressure and achieving glycemic control as a means of minimizing the rate of CKD progression. Thus, the The Eighth Joint National Committee (JNC8) Guidelines for Hypertension in adults have recommended target blood pressure of $<140 / 90$ mmHg, ${ }^{62}$ whereas the American Heart Association 2017 guidelines have recently recommended target blood pressure of $<130 / 80 \mathrm{mmHg}$ and suggest the use of ACE inhibitors if albuminuria is $>300 \mathrm{mg} /$ day. $^{63}$

\section{Conclusion}

HIVAN is a rapidly progressing kidney disorder that affects HIV-positive individuals predominantly of African American ancestry. Clinical and genetic risk factors such as low CD4 count, high viral load, high-grade proteinuria, presence of comorbidities such as hypertension and diabetes, and APOL1 polymorphism contribute to greater progression of kidney disease in this population. We now have a greater understanding of the cellular mechanisms by which APOL1 risk variants may affect cellular function through dysregulation of cellular signaling and mitochondrial function, though more work is needed in these areas.

This review has a number of limitations. First, this was not a meta-analysis of multiple previous studies, but rather an overview of the general understanding of HIVAN pathophysiology. Many studies described are small retrospective observational studies which have inherent limitations. This review serves to provide the evidence behind the current, guideline-based strategies for HIVAN management. Further, we wish to highlight active areas of research on the pathophysiology of HIVAN and optimization of graft survival outcomes of HIV-positive kidney transplantation recipients. 


\section{Acknowledgment}

MGA was supported by The National Institute of Diabetes and Digestive and Kidney Diseases 5P01DK056492-13.

\section{Disclosure}

The authors report no conflicts of interest in this work.

\section{References}

1. Mocroft A, Reiss P, Gasiorowski J, et al. Serious fatal and nonfatal non-AIDS-defining illnesses in Europe. J Acquir Immune Defic Syndr. 2010;55(2):262-270.

2. Waheed S, Atta MG. Predictors of HIV-associated nephropathy. Expert Rev Anti Infect Ther. 2014;12(5):555-563.

3. Fogo AB, Lusco MA, Najafian B, Alpers CE. AJKD atlas of renal pathology: HIV-associated nephropathy (HIVAN). Am J Kidney Dis. 2016;68(2):e13-e14.

4. Swanepoel CR, Atta MG, D'Agati VD, et al. Kidney disease in the setting of HIV infection: conclusions from a kidney disease: improving global outcomes (KDIGO) controversies conference. Kidney Int. 2018;93(3):545-559.

5. Ahuja T, S, Borucki M, Funtanilla M, Shahinian V, Hollander M, Rajaraman S. Is the prevalence of HIV-associated nephropathy decreasing? Am J Nephrol. 1999;19(6):655-659.

6. Razzak Chaudhary S, Workeneh BT, Montez-Rath ME, Zolopa AR, Klotman PE, Winkelmayer WC. Trends in the outcomes of end-stage renal disease secondary to human immunodeficiency virus-associated nephropathy. Nephrol Dial Transplantat. 2015;30(10):1734-1740.

7. Genovese G, Friedman DJ, Ross MD, et al. Association of trypanolytic ApoL1 variants with kidney disease in African Americans. Science. 2010;329(5993):841-845.

8. Ko W-Y, Rajan P, Gomez F, et al. Identifying darwinian selection acting on different human $A P O L 1$ variants among diverse African populations. Am J Hum Genet. 2013;93(1):54-66.

9. Kopp JB, Nelson GW, Sampath K, et al. APOL1 Genetic variants in focal segmental glomerulosclerosis and HIV-associated nephropathy. J Am Soc Nephrol. 2011;22(11):2129-2137.

10. Lipkowitz MS, Freedman BI, Langefeld CD, et al. Apolipoprotein L1 gene variants associate with hypertension-attributed nephropathy and the rate of kidney function decline in African Americans. Kidney Int. 2013;83(1):114-120.

11. Beckerman P, Bi-Karchin J, Park A, et al. Transgenic expression of human APOL1 risk variants in podocytes induces kidney disease in mice. Nat. Med. 23(4):429-438.

12. Granado D, Muller D, Krausel V, et al. Intracellular APOL1 risk variants cause cytotoxicity accompanied by energy depletion. JAm Soc Nephrol. 2017;28(11):3227-3238.

13. Olabisi OA, Zhang JY, VerPlank L, et al. APOL1 kidney disease risk variants cause cytotoxicity by depleting cellular potassium and inducing stressactivated protein kinases. Proc Natl Acad Sci USA. 2016;113(4):830-837.

14. Ma L, Chou JW, Snipes JA, et al. APOL1 renal-risk variants induce mitochondrial dysfunction. JAm Soc Nephrol. 2017;28(4):1093-1105.

15. FuY, Zhu J, Richman A et al. APOL1-G1 Nephrocytes induces hypertrophy and accelerates cell death. JAm Soc Nephrol. 2017;28(4):1106-1116.

16. Kruzel-Davila E, Shemer R, Ofir A, et al. APOL1-mediated cell injury involves disruption of conserved trafficking processes. J Am Soc Nephrol. 2017;28(4):1117-1130.

17. Kruzel-Davila, E., Wasser, W.G., Aviram, S., Skorecki, K. APOL1 nephropathy: from gene to mechanisms of kidney injury. Nephrol Dial Transplant. 2016;31(3):349-358.

18. Ryom L, Kirk O, Lundgren JD, et al. Advanced chronic kidney disease, end-stage renal disease and renal death among HIV-positive individuals in Europe. HIV Med. 2013;14(8):503-508.
19. Nadkarni GN, Konstantinidis I, Wyatt CM. HIV and the aging kidney. Curr Opin HIV AIDS. 2014;9(4):340-345.

20. Cheung CY, Wong KM, Lee MP, et al. Prevalence of chronic kidney disease in Chinese HIV-infected patients. Nephrol Dial Transplant. 2007;22(11):3186-3190.

21. Yanagisawa N, Ando M, Ajisawa A, et al. Clinical characteristics of kidney disease in Japanese HIV-infected patients. Nephron Clin Pract. 2011;118(3):c285-c291.

22. Bige N, Lanternier F, Viard J-P, et al. Presentation of HIV-associated nephropathy and outcome in HAART-treated patients. Nephrol Dial Transplant. 2011;27(3):1114-1121.

23. Atta MG, Choi MJ, Longenecker JC, et al. Nephrotic range proteinuria and CD4 count as noninvasive indicators of HIV-associated nephropathy. Am J Med. 2005;118(11):1288.

24. U.S. Renal Data System. USRDS 2007 Annual Data Report: Atlas of Chronic Kidney Disease and End-Stage Renal Disease in the United States. Bethesda, MD: National Institutes of Health, National Institute of Diabetes and Digestive and Kidney Diseases; 2007.

25. Coresh J, Byrd-Holt D, Astor BC, et al. Chronic kidney disease awareness, prevalence, and trends among U.S. adults, 1999 to 2000. $J$ Am Soc Nephrol. 2005;16(1):180-188.

26. Brown TT, Cole SR, Li X, et al. Antiretroviral therapy and the prevalence and incidence of diabetes mellitus in the multicenter AIDS cohort study. Arch Intern Med. 2005;165(10):1179-1184.

27. Brown TT, Li X, Cole SR, et al. Cumulative exposure to nucleoside analogue reverse transcriptase inhibitors is associated with insulin resistance markers in the Multicenter AIDS Cohort Study. AIDS. 2005; 19(13):1375-1383.

28. Tien PC, Schneider MF, Cole SR, et al. Antiretroviral therapy exposure and incidence of diabetes mellitus in the Women's Interagency HIV Study. AIDS. 2007;21(13):1739-1745.

29. Gazzaruso C, Bruno R, Garzaniti A, et al. Hypertension among HIV patients: prevalence and relationships to insulin resistance and metabolic syndrome. J Hypertens. 2003;21(7):1377-1382.

30. Jung O, Bickel M, Ditting T, et al. Hypertension in HIV-1-infected patients and its impact on renal and cardiovascular integrity. Nephrol Dial Transplant. 2004;19(9):2250-2258.

31. Lescure FX, Flateau C, Pacanowski J, et al. HIV-associated kidney glomerular diseases: changes with time and HAART. Nephrol Dial Transplant. 2012;27(6):2349-2355.

32. Atta MG, Longenecker JC, Fine DM, et al. Sonography as a predictor of human immunodeficiency virus-associated nephropathy. J Ultrasound Med. 2004;23(5):603-610.

33. Berliner A R, Fine DM, Lucas GM, et al. Observations on a cohort of HIV-infected patients undergoing native renal biopsy. Am J Nephrol. 2008;28:478-486.

34. Williams DI, Williams DJ, Williams IG, Unwin RJ, Griffiths MH, Miller RF. Presentation, pathology, and outcome of HIV associated renal disease in a specialist centre for HIV/AIDS. Sex Transm Infect. 1998;74(3):179-184.

35. Estrella M, Fine DM, Gallant JE, et al. HIV type 1 RNA level as a clinical indicator of renal pathology in HIV-infected patients. Clin Infect Dis. 2006;43(3):377-380.

36. Izzedine $\mathrm{H}$, Acharya V, Wirden $\mathrm{M}$, et al. Role of HIV-1 DNA levels as clinical marker of HIV-1-associated nephropathies. Nephrol Dial Transplant. 2010;26(2):580-583.

37. Eitner F, Cui Y, Hudkins KL, et al. Chemokine receptor (CCR5) expression in human kidneys and in the HIV infected macaque. Kidney Int. 1998;54(6):1945-1954.

38. Diana NE, Naicker S. Update on current management of chronic kidney disease in patients with HIV infection. Int J Nephrol Renovasc Dis. 2016;9:223-234.

39. Hatsukari I, Singh P, Hitosugi N, et al. DEC-205-Mediated internalization of HIV-1 results in the establishment of silent infection in renal tubular cells. J Am Soc Nephrol. 2007;18(3):780-787. 
40. Atta MG, Gallant JE, Rahman MH, et al. Antiretroviral therapy in the treatment of HIV-associated nephropathy. Nephrol Dial Transplantat. 2006;21(10):2809-2813.

41. Lucas GM, Eustace JA, Sozio S, Mentari EK, Appiah KA, Moore RD. Highly active antiretroviral therapy and the incidence of HIV1-associated nephropathy. AIDS. 2004;18(3):541-546.

42. Post FA, Campbell LJ, Hamzah L, et al. Predictors of renal outcome in HIV-associated nephropathy. Clin Infect Dis. 2008;46(8):1282-1289.

43. Casas JP, Chua W, Loukogeorgakis S, et al. Effect of inhibitors of the renin-angiotensin system and other antihypertensive drugs on renal outcomes: systematic review and meta-analysis. Lancet. 2005;366(9502):2026-2033.

44. Alsauskas ZC, Medapalli RK, Ross MJ. Expert opinion on pharmacotherapy of kidney disease in HIV-infected patients. Expert Opin Pharmacother. 2011;12(5):691-704.

45. Kimmel PL, Mishkin GJ, Umana WO. Captopril and renal survival in patients with human immunodeficiency virus nephropathy. Am J Kidney Dis. 1996;28(2):202-208.

46. Wei A, Burns GC, Williams BA, Mohammed NB, Visintainer P, Sivak SL. Long-term renal survival in HIV-associated nephropathy with angiotensin-converting enzyme inhibition. Kidney Int. 2003;64(4): 1462-1471.

47. Lucas GM, Ross MJ, Stock PG, et al. HIV Medicine Association of the Infectious Diseases Society of America Clinical practice guideline for the management of chronic kidney disease in patients infected with HIV: 2014 update by the HIV Medicine Association of the Infectious Diseases Society of America. Clin Infect Dis. 2014;59(9): e96-e138.

48. Eustace JA, Nuermberger E, Choi M, Scheel PJ Jr, Moore R, Briggs WA. Cohort study of the treatment of severe HIV-associated nephropathy with corticosteroids. Kidney Int. 2000;58(3):1253-1260.

49. Laradi A, Mallet A, Beaufils H, Allouache M, Martinez F. HIVassociated nephropathy: outcome and prognosis factors. J Am Soc Nephrol. 1998;9(12):2327-2335.

50. Jotwani V, Li Y, Grunfeld C, Choi AI, Shlipak MG. Risk factors for ESRD in HIV-infected individuals: traditional and HIV-related factors. Am J Kidney Dis. 2012;59(5):628-635.
51. Rasch MG, Helleberg M, Feldt-Rasmussen B, et al. Increased risk of dialysis and end-stage renal disease among HIV patients in Denmark compared with the background population. Nephrol Dial Transplant. 2014;29(6):1232-1238.

52. Dave MB, Shabih K, Blum S. Maintenance hemodialysis in patients with HIV-associated nephropathy. Clin Nephrol. 1998;50(6):367-74.

53. Atta MG, Fine DM, Kirk GD, Mehta SH, Moore RD, Lucas GM Survival during renal replacement therapy among African Americans infected with HIV type 1 in urban Baltimore, Maryland. Clin Infect Dis. 2007;45(12):1625-1632.

54. Curi MA, Pappas PJ, Silva MB Jr, et al. Hemodialysis access: influence of the human immunodeficiency virus on patency and infection rates. J Vasc Surg. 1999;29(4):608-616.

55. Recommendations for preventing transmission of infections among chronic hemodialysis patients. MMWR Recomm Rep. 2001;50(RR-5): $1-43$.

56. Stock PG, Barin B, Murphy B, et al. Outcomes of kidney transplantation in HIV-infected recipients. N Engl J Med. 2010;363(21):2004-2014.

57. Waheed S, Sakr A, Chheda ND, et al. Outcomes of Renal Transplantation in HIV-1 Associated Nephropathy. PLoS One. 2015;10(6):e0129702.

58. Muller E, Barday Z, Mendelson M, Kahn D. HIV-positive-to-HIVpositive kidney transplantation-results at 3 to 5 years. $N$ Engl J Med. 2015;372:613-620.

59. Durand CM, Segev D, Sugarman J. Realizing HOPE: the ethics of organ transplantation from HIV-positive donors. Ann Intern Med. 2016;165:138-142.

60. Muller E, Barday Z. HIV-positive donor selection for HIV-positive transplant recipients. J Am Soc Nephrol. Epub 2018 Jan 12.

61. Fine DM, Perazella MA, Lucas GM, Atta MG. Kidney biopsy in HIV: beyond HIV-associated nephropathy. Am J Kidney Dis. 2008;51(3): 504-514.

62. James PA, Ortiz E, Carter BL, et al. 2014 evidence-based guideline for the management of high blood pressure in adults: (JNC8). JAMA. 2014;311(5):507-520.

63. Philip Greenland, Eric Peterson. The New 2017 ACC/AHA guidelines "up the pressure" on diagnosis and treatment of hypertension. JAMA. 2017;318(21):2083-2084
HIV/AIDS - Research and Palliative Care

\section{Publish your work in this journal}

HIV/AIDS - Research and Palliative Care is an international, peerreviewed open access journal focusing on advances in research in HIV its clinical progression and management options including antiviral treatment, palliative care and public healthcare policies to control viral spread. The journal is included in PubMed. The manuscript man-

\section{Dovepress}

agement system is completely online and includes a very quick and fair peer-review system, which is all easy to use. Visit http://www.dovepress com/testimonials.php to read real quotes from published authors. 